\title{
DID LEGAL REGULATIONS CHANGE THE REPORTING FREQUENCY OF SHARP INJURIES OF MEDICAL PERSONNEL? STUDY FROM 36 HOSPITALS IN ŁÓDŹ PROVINCE, POLAND
}

\author{
ANNA GARUS-PAKOWSKA ${ }^{1}$, MARIUSZ GÓRAJSKI ${ }^{2}$, and FRANCISZEK SZATKO ${ }^{1}$ \\ ${ }^{1}$ Medical University of Lodz, Łódź, Poland \\ Department of Hygiene and Health Promotion \\ ${ }^{2}$ University of Lodz, Łódź, Poland \\ Department of Econometrics
}

\begin{abstract}
Objectives: The aim of the study has been to analyze the epidemiological data on sharp injuries among health care workers before and after the implementation of regulations related to the conduct of the register of sharp injuries. Material and Methods: We hypothesized that the introduction of legislation would change the existing low reportability of sharp injuries and reporting incidents would increase. In Poland the binding regulations, dating back to 2013, require the employer to keep a record of sharp injuries. Therefore, we compared the data from before and after the entry regulations. Data was collected from the records of occupational exposure/accidents at work in hospitals in the Lódź Province during 2010-2014. The feedback came from 36 hospitals (return index $=51.5 \%$ ), representing a total annual average of 13211 medical workers. Results: The incidence of injuries did not change significantly over the period 2010-2014, and the number of reported injuries in 2014 (the year when the Regulation had already been effective) was even lower than in the previous years. The average annual injury index was 12.31 injuries per 1000 employees (95\% confidence interval: 11.48-13.16/1000). The incidence of injuries among nurses was significantly higher than in other groups of medical professionals $(\mathrm{p}<0.05)$. These injuries most often occur while using needles $(\mathrm{p}<0.05)$. Conclusions: The obligation to record occupational exposures set forth in current regulations is not likely to improve the reliability of reporting the incidents actually taking place. Further research should focus on identifying barriers to reporting cases of exposure to potentially infectious material. Action should be taken to raise awareness of medical personnel about the possible effects of exposure to infectious material, in particular, the benefits of the implementation of early post-exposure procedures. Perhaps it will increase the reporting frequency of sharp injuries of medical personnel. Int J Occup Med Environ Health 2018;31(1):37-46
\end{abstract}

Key words:

Blood, Occupational exposure, Infectious diseases, Medical personnel, Registration, Potentially infectious material

Funding: work funded by the Medical University of Lodz under research item No. 502-03/6-024-01/502-64-049: "Exposure assessment of health care workers to infectious material." Program manager: Anna Garus-Pakowska, Ph.D.

Received: June 20, 2016. Accepted: October 25, 2016.

Corresponding author: A. Garus-Pakowska, Medical University of Lodz, Department of Hygiene and Health Promotion, pl. Hallera 1, 90-647 Łódź, Poland (e-mail: anna.garus-pakowska@umed.lodz.pl). 


\section{INTRODUCTION}

Patient care is associated with continuous exposure to harmful biological agents found in the work environment, such as pathogenic bacteria, viruses, fungi and protozoa [1]. Since occupational exposure to blood affects the majority of medical workers, on 10 May, 2010, the Council of the European Union adopted Directive 2010/32/EU [2], which is an implementation of the Framework Agreement on preventing sharp injuries in hospital and healthcare sector signed on 17 July, 2009 by the European social partners: the European Hospital and Healthcare Employers' Association (HOSPEEM) and the European Federation of Public Service Unions (EPSU).

The ordinance of the Minister of Health on occupational health and safety when performing work associated with the risk of injury by sharp tools used when supplying health services is the Polish adaptation of the provisions of Directive 2010/32/EU [3]. The Regulation, which came into force in 2013, imposes an obligation on the employer to keep a register of sharp injuries. This register serves as the starting point for the employer who is expected to analyze the circumstances and causes of injuries and propose measures intended to reduce the number of those injuries. At the moment, reliable information on how many such injuries occur in the workplaces in Poland is not available. No precise data is available on the number of events associated with accidental tissue disruption in Poland.

According to data from the Central Statistical Office in Poland in 2013, in the sector of health care and social welfare, a total of 8982 accidents were reported, out of which 1480 events had been caused by sharp objects [4]. According to the Center for Disease Control and Prevention of Infectious Diseases (CDC), in the United States the annual number of injuries among the hospital staff is 385000 [5]. Throughout Europe, needle stick injuries are also one of the greatest problems in health and safety. A study by Prüss-Üstün et al. found that workers in European healthcare services could expect around 0.64 needle stick injuries on average each year. Affecting around 6 million employees in the healthcare sector, this corresponds to nearly 4 million injuries of this type each year [6]. Note, however, that these figures are merely estimates, and the problem is that the workers themselves fail to report the injuries, which is confirmed by both the Polish and the study of other countries [7-10]. A huge proportion of the events is not reported, and if the employer is not aware of those events, he/she sees no need to invest in safe equipment.

The aim of the study has been a retrospective comparative analysis of epidemiological data on sharp injuries among medical staff in the Kódź Province before and after the implementation of regulations related to the conduct of the register of sharp injuries.

The study was dealing with the following questions:

- Has the current regulation [3] improved the frequency of reporting sharp injuries?

- What was the professional category of employees who were most exposed to the sharp injuries?

- Which of the tools used by health care professionals were usually responsible for the injury?

- During which actions do injuries occur most often?

\section{MATERIAL AND METHODS}

The research focused on the hypothesis that recently introduced legislation would improve the current low reportability of sharp injuries. To verify the hypothesis, we compared the data before adopting and after revoking the regulation of the Minister of Health [3]. Compared periods are not symmetrical, however, we wanted to explore the initial impact of the implementation of the new regulation.

The study employs a questionnaire sheet in the form of a table on sharp injuries among medical staff, developed specifically for the purpose of this study. The questionnaire sheets were sent through the Internet to all 62 hospitals located in the Province of Łódź, Poland. These were 
the hospitals of varying sizes and varying degrees of reference: municipal, provincial, clinical, private. In addition, directors of all hospitals included in the database were contacted on the phone to convince them about the advisability of collecting data on the exposure of the employees to infectious material. The survey was anonymous.

Pursuant to the relevant Polish Ordinance [3], the first report on injuries in the hospitals should be prepared no later than 28 February 2014, and then updated once every 6 months. Data for 2014 originates from those registers. Data from previous years was obtained from reports on accidents at work, or other registers kept by the teams dealing with the nosocomial infections and/or other occupational safety and health (OSH) facilities in hospitals. The feedback came from 36 hospitals (return index $=58.1 \%$ ), representing a total annual average of 13211 medical workers. Hospitals that responded to the invitation to participate in the study were of varied sizes: employed from 7 to 2308 health care workers (567 on average).

To assess the prevalence of injuries, rates of injuries were calculated per 1000 workers/year (with 95\% confidence intervals $(\mathrm{CI})$ ). In order to verify the study hypotheses and to answer research questions, Fisher-Snedecor tests were performed (to verify the differences between the fre- quencies of injuries in each year), Pearson's $\mathrm{Chi}^{2}$ tests of independence (for profession + tool and tool + year variables) were performed. The level of statistical significance was set at $\mathrm{p} \leq 0.05$. The analysis and interpretation of the data were done with IBM SPSS Statistics 22 and Microsoft Excel 2010.

The study protocol was approved by the Bioethics Committee of the Medical University of Lodz (Document No. RNN/163/14/KB of 11.02.2014) in full accordance with the Declaration of Helsinki of the World Medical Association.

\section{RESULTS}

In the 5-year period, 813 injuries by medical sharps were recorded. The average annual number of the injuries per 1000 workers was 12 . The average empirical likelihood of injuries in respective years ranged between 1.09\% and $1.38 \%$, and showed a weak downward trend. The likelihood of injury in the consecutive years 2010-2014 among medical personnel was the same $(\mathrm{F}=0.017$, critical value $\left.\mathrm{F}^{*}=2.37, \mathrm{p} \leq 0.05\right)$ (Table 1$)$.

The most frequent injuries occurred among nurses and midwives, for whom the incidence of injury in 20102014 ranged between 70.3-81.8\% (average 76\%). Each year, on average, physicians were victims of every 5 th in-

Table 1. Sharp injuries among medical employees reported in the Łódź Province hospitals, Poland, 2010-2014

\begin{tabular}{|c|c|c|c|c|c|c|c|}
\hline \multirow{2}{*}{ Variable } & \multicolumn{6}{|c|}{ Reported data from consecutive years } & \multirow{2}{*}{$\begin{array}{l}\text { Total } \\
(\mathrm{M})\end{array}$} \\
\hline & 2010 & 2011 & 2012 & 2013 & 2014 & total & \\
\hline Sharp injuries [n] & 166 & 148 & 164 & 180 & 155 & 813 & 162.60 \\
\hline $\begin{array}{l}\text { Medical } \\
\text { employees [n] }\end{array}$ & 12011 & 12815 & 12824 & 14152 & 14255 & - & 13211.00 \\
\hline $\begin{array}{l}\text { Sharp injuries/ } \\
\text { medical employees } \\
\text { rate }[\mathrm{n} / 1000 \\
(95 \% \mathrm{CI})]\end{array}$ & $\begin{array}{c}13.82 \\
(11.81-15.98)\end{array}$ & $\begin{array}{c}11.55 \\
(9.77-13.47)\end{array}$ & $\begin{array}{c}12.79 \\
(10.91-14.80)\end{array}$ & $\begin{array}{c}12.72 \\
(10.94-14.63)\end{array}$ & $\begin{array}{c}10.87 \\
(9.23-12.64)\end{array}$ & - & $\begin{array}{c}12.31 \\
(11.48-13.16)\end{array}$ \\
\hline Fisher-Snedecor test & \multicolumn{5}{|c|}{$\mathrm{F}=0.017, \mathrm{~F}^{*}=2.37, \mathrm{p} \leq 0.05$} & - & - \\
\hline
\end{tabular}

$\mathrm{CI}$ - confidence interval; $\mathrm{M}$ - mean.

* Critical value. 
Table 2. Sharp injuries among medical employees reported in the Łódź Province hospitals, Poland, 2010-2014, by occupational group

\begin{tabular}{|c|c|c|c|c|c|c|c|}
\hline \multirow{2}{*}{ Variable } & \multicolumn{6}{|c|}{ Sharp injuries in consecutive years } & \multirow{2}{*}{$\mathrm{p}$} \\
\hline & 2010 & 2011 & 2012 & 2013 & 2014 & total & \\
\hline Physician injuries [n] & 35 & 24 & 34 & 33 & 43 & 169 & $<0.001$ \\
\hline within profession [\%] & 20.7 & 14.2 & 20.1 & 19.5 & 25.4 & 100.0 & \\
\hline within year [\%] & 21.1 & 16.2 & 20.7 & 18.3 & 27.7 & 20.8 & \\
\hline Nurse and midwife injuries [n] & 128 & 121 & 124 & 136 & 109 & 618 & $<0.001$ \\
\hline within profession [\%] & 20.7 & 19.6 & 20.1 & 22.0 & 17.6 & 100.0 & \\
\hline within year $[\%]$ & 77.1 & 81.8 & 75.6 & 75.6 & 70.3 & 76.0 & \\
\hline Paramedical injuries [n] & 3 & 3 & 6 & 11 & 3 & 26 & $<0.001$ \\
\hline within profession [\%] & 11.5 & 11.5 & 23.1 & 42.3 & 11.5 & 100.0 & \\
\hline within year [\%] & 1.8 & 2.0 & 3.7 & 6.1 & 1.9 & 3.2 & \\
\hline Total [n] & 166 & 148 & 164 & 180 & 155 & 813 & \\
\hline within profession [\%] & 20.4 & 18.2 & 20.2 & 22.1 & 19.1 & 100.0 & \\
\hline within year [\%] & 100.0 & 100.0 & 100.0 & 100.0 & 100.0 & 100.0 & \\
\hline
\end{tabular}

jury $(20.8 \%)$. Over the 5 years, only 26 cases of injuries $(3.2 \%)$ were recorded among paramedics. The prevalence of injuries among nurses and midwives was significantly higher $(\mathrm{p}<0.05)$ than among physicians and paramedics (Table 2).

In all occupational groups, the most common injury was by needle (76.1\% of all injuries). Among the nurses, the proportion of needle stick injuries was $78.2 \%$, while among physicians and paramedics the proportions of those injuries were similar, $69.8 \%$ and $69.2 \%$, respectively. The results of the test of independence $\mathrm{Chi}^{2}$ (Pearson's Chi ${ }^{2}$ ) confirmed a significant correlation between occupation and the tool involved in the injury $\left(\mathrm{Chi}^{2}=32.618, \mathrm{p} \leq 0.05\right)$. At the same time, the prevalence of injuries by needle was significantly higher $(\mathrm{p} \leq 0.05)$ than the prevalence of injuries by other medical instruments (Table 3 ).

The incidence of injuries by various tools in 2010-2014 is presented in the Table 4. Pearson's test of independence performed by varying the tool and the year in which the injury occurred showed no significant relationship between them; the distribution of tool injuries is constant in time.
The Table 5 shows distribution of tools responsible for the injuries in different occupational groups during consecutive years 2010, 2011, 2012, 2013 and 2014. Only for 2010, the results of Pearson's Chi test confirm significant changes in the distribution of tools causing injuries in different occupational groups. During that year, a significant dominance is evident of the frequency of needle stick injuries in the group of nurses, midwives and physicians. The nurses were the group of medical staff most frequently experiencing percutaneous exposure to infectious material. Needle stick injuries were most frequently reported instances of injuries by sharp tools (Table 6). The types of medical procedures and operations during which the injury occurred include:

- blood sampling,

- subcutaneous injection,

- cleaning of tools after surgery,

- disposing of a needle into a container for medical waste,

- intramuscular injection,

- administration of insulin, 
Table 3. Sharp injuries among medical employees reported in the Lódź Province hospitals, Poland, 2010-2014, by occupational group and used medical tools

\begin{tabular}{|c|c|c|c|c|c|c|}
\hline \multirow[b]{2}{*}{ Variable } & \multicolumn{6}{|c|}{ Sharp injuries by tool } \\
\hline & needle & cannula & stylet & $\begin{array}{l}\text { lancet/surgical } \\
\text { knife }\end{array}$ & others & total \\
\hline Physician injuries [n] & 118 & 7 & 10 & 30 & 4 & 169 \\
\hline within profession [\%] & 69.8 & 4.1 & 5.9 & 17.8 & 2.4 & 100.0 \\
\hline within tool [\%] & 19.1 & 29.2 & 20.8 & 40.0 & 8.5 & 20.8 \\
\hline Nurse and midwife injuries [n] & 483 & 16 & 36 & 45 & 38 & 618 \\
\hline within profession [\%] & 78.2 & 2.6 & 5.8 & 7.3 & 6.1 & 100.0 \\
\hline within tool [\%] & 78.0 & 66.7 & 75.0 & 60.0 & 80.9 & 76.0 \\
\hline Paramedical injuries [n] & 18 & 1 & 2 & 0 & 5 & 26 \\
\hline within profession [\%] & 69.2 & 3.8 & 7.7 & 0.0 & 19.2 & 100.0 \\
\hline within tool [\%] & 2.9 & 4.2 & 4.2 & 0.0 & 10.6 & 3.2 \\
\hline Total [n] & 619 & 24 & 48 & 75 & 47 & 813 \\
\hline within profession [\%] & 76.1 & 3.0 & 5.9 & 9.2 & 5.8 & 100.0 \\
\hline within tool [\%] & 100.0 & 100.0 & 100.0 & 100.0 & 100.0 & 100.0 \\
\hline $\mathrm{p}$ & $<0.001$ & $<0.001$ & $<0.001$ & $<0.001$ & $<0.001$ & - \\
\hline Pearson's Chi test & \multicolumn{6}{|c|}{$\mathrm{Chi}^{2}=32.618$ for $\mathrm{p}<0.0001$} \\
\hline
\end{tabular}

Table 4. Sharp injuries among medical employees reported in the Łódź Province hospitals, Poland, 2010-2014, by years and used medical tools

\begin{tabular}{ccccccc}
\hline & \multicolumn{5}{c}{ Sharp injuries by tool } \\
\cline { 2 - 7 } Variable & needle & cannula & stylet & $\begin{array}{c}\text { lancet/surgical } \\
\text { knife }\end{array}$ & others & total \\
\hline 2010 injuries [n] & 136 & 2 & 9 & 12 & 7 & 166 \\
within year [\%] & 81.9 & 1.2 & 5.4 & 7.2 & 4.2 & 100.0 \\
within tool [\%] & 22.0 & 8.3 & 18.8 & 16.0 & 14.9 & 20.4 \\
2011 injuries [n] & 109 & 4 & 12 & 17 & 6 & 148 \\
within year [\%] & 73.6 & 2.7 & 8.1 & 11.5 & 4.1 & 100.0 \\
within tool [\%] & 17.6 & 16.7 & 25.0 & 22.7 & 12.8 & 18.2 \\
2012 injuries [n] & 130 & 4 & 6 & 14 & 10 & 164 \\
within year [\%] & 79.3 & 2.4 & 3.7 & 8.5 & 6.1 & 100.0 \\
within tool [\%] & 21.0 & 16.7 & 12.5 & 18.7 & 21.3 & 20.2 \\
2013 injuries [n] & 131 & 5 & 13 & 18 & 13 & 180 \\
within year [\%] & 72.8 & 2.8 & 7.2 & 10.0 & 7.2 & 100.0 \\
within tool [\%] & 21.2 & 20.8 & 27.1 & 24.0 & 27.7 & 22.1 \\
\hline
\end{tabular}


Table 4. Sharp injuries among medical employees reported in the Lódź Province hospitals, Poland, 2010-2014, by years and used medical tools - cont.

\begin{tabular}{ccccccc}
\hline \multirow{2}{*}{ Variable } & \multicolumn{5}{c}{ Sharp injuries by tool } \\
\cline { 2 - 7 } & needle & cannula & stylet & $\begin{array}{c}\text { lancet/surgical } \\
\text { knife }\end{array}$ & others & total \\
\hline 2014 injuries [n] & 113 & 9 & 8 & 14 & 11 & 155 \\
within year [\%] & 72.9 & 5.8 & 5.2 & 9.0 & 7.1 & 100.0 \\
within tool [\%] & 18.3 & 37.5 & 16.7 & 18.7 & 23.4 & 19.1 \\
Total [n] & 619 & 24 & 48 & 75 & 47 & 813 \\
within year [\%] & 76.1 & 3.0 & 5.9 & 9.2 & 5.8 & 100.0 \\
within tool [\%] & 100.0 & 100.0 & 100.0 & 100.0 & 100.0 & 100.0 \\
Pearson's Chi ${ }^{2}$ test & & \multicolumn{7}{c}{ Chi $^{2}=17.975$ for $\mathrm{p}=0.116$} & & - \\
\hline
\end{tabular}

Table 5. Sharp injuries among medical employees reported in the Łódź Province hospitals, Poland, 2010-2014, by years, occupational group, and used medical tools

\begin{tabular}{|c|c|c|c|c|c|c|c|c|}
\hline \multirow{2}{*}{ Year and occupation } & \multicolumn{6}{|c|}{$\begin{array}{l}\text { Sharp injuries by tool } \\
{[\mathrm{n}(\%)]}\end{array}$} & \multirow{2}{*}{$\begin{array}{l}\text { Pearson's } \\
\text { Chi }^{2}\end{array}$} & \multirow{2}{*}{$\mathrm{p}$} \\
\hline & needle & cannula & stylet & $\begin{array}{c}\text { lancet/ } \\
\text { surgical knife }\end{array}$ & others & total & & \\
\hline \multicolumn{9}{|l|}{2010} \\
\hline physician & $27(77.1)$ & $0(0.0)$ & $2(5.7)$ & $5(14.3)$ & $1(2.9)$ & $35(100.0)$ & & \\
\hline nurse and midwife & $109(85.2)$ & $2(1.6)$ & $7(5.5)$ & $7(5.5)$ & $3(2.3)$ & $128(100.0)$ & & \\
\hline paramedical & $0(0.0)$ & $0(0.0)$ & $0(0.0)$ & $0(0.0)$ & $3(100.0)$ & $3(100.0)$ & & \\
\hline total & $136(81.9)$ & $2(1.2)$ & $9(5.4)$ & $12(7.2)$ & $7(4.2)$ & $166(100.0)$ & 73.145 & $<0.001$ \\
\hline \multicolumn{9}{|l|}{2011} \\
\hline physician & $17(70.8)$ & $1(4.2)$ & $0(0.0)$ & $6(25.0)$ & $0(0.0)$ & $24(100.0)$ & & \\
\hline nurse and midwife & $90(74.4)$ & $3(2.5)$ & $11(9.1)$ & $11(9.1)$ & $6(5.0)$ & $121(100.0)$ & & \\
\hline paramedical & $2(66.7)$ & $0(0.0)$ & $1(33.3)$ & $0(0.0)$ & $0(0.0)$ & $3(100.0)$ & & \\
\hline total & $109(73.6)$ & $4(2.7)$ & $12(8.1)$ & $17(11.5)$ & $6(4.1)$ & $148(100.0)$ & 10.896 & 0.208 \\
\hline \multicolumn{9}{|l|}{2012} \\
\hline physician & $26(76.5)$ & $2(5.9)$ & $0(0.0)$ & $5(14.7)$ & $1(2.9)$ & $34(100.0)$ & & \\
\hline nurse and midwife & $99(79.8)$ & $1(0.8)$ & $6(4.8)$ & $9(7.3)$ & $9(7.3)$ & $124(100.0)$ & & \\
\hline paramedical & $5(83.3)$ & $1(16.7)$ & $0(0.0)$ & $0(0.0)$ & $0(0.0)$ & $6(100.0)$ & & \\
\hline total & $130(79.3)$ & $4(2.4)$ & $6(3.7)$ & $14(8.5)$ & $10(6.1)$ & $164(100.0)$ & 13.435 & 0.098 \\
\hline \multicolumn{9}{|l|}{2013} \\
\hline physician & $21(63.6)$ & $1(3.0)$ & $4(12.1)$ & $7(21.2)$ & $0(0.0)$ & $33(100.0)$ & & \\
\hline nurse and midwife & $102(75.0)$ & $4(2.9)$ & $8(5.9)$ & $11(8.1)$ & $11(8.1)$ & $136(100.0)$ & & \\
\hline paramedical & $8(72.7)$ & $0(0.0)$ & $1(9.1)$ & $0(0.0)$ & $2(18.2)$ & $11(100.0)$ & & \\
\hline total & $131(72.8)$ & $5(2.8)$ & $13(7.2)$ & $18(10.0)$ & $13(7.2)$ & $180(100.0)$ & 12.385 & 0.135 \\
\hline
\end{tabular}


Table 5. Sharp injuries among medical employees reported in the Lódź Province hospitals, Poland, 2010-2014, by years, occupational group, and used medical tools - cont.

\begin{tabular}{|c|c|c|c|c|c|c|c|c|}
\hline \multirow{2}{*}{ Year and occupation } & \multicolumn{6}{|c|}{$\begin{array}{c}\text { Sharp injuries by tool } \\
{[\mathrm{n}(\%)]}\end{array}$} & \multirow{2}{*}{$\begin{array}{l}\text { Pearson's } \\
\text { Chi }^{2}\end{array}$} & \multirow{2}{*}{$\mathrm{p}$} \\
\hline & needle & cannula & stylet & $\begin{array}{c}\text { lancet/ } \\
\text { surgical knife }\end{array}$ & others & total & & \\
\hline \multicolumn{9}{|l|}{2014} \\
\hline physician & $27(62.8)$ & $3(7.0)$ & $4(9.3)$ & $7(16.3)$ & $2(4.7)$ & $43(100.0)$ & & \\
\hline nurse and midwife & $83(76.1)$ & $6(5.5)$ & $4(3.7)$ & $7(6.4)$ & $9(8.3)$ & $109(100.0)$ & & \\
\hline paramedical & $3(100.0)$ & $0(0.0)$ & $0(0.0)$ & $0(0.0)$ & $0(0.0)$ & $3(100.0)$ & & \\
\hline total & $113(72.9)$ & $9(5.8)$ & $8(5.2)$ & $14(9.0)$ & $11(7.1)$ & $155(100.0)$ & 7.784 & 0.455 \\
\hline Pearson's Chi test* & \multicolumn{5}{|c|}{$\mathrm{Chi}^{2}=32.618$ for $\mathrm{p}<0.001$} & - & - & - \\
\hline
\end{tabular}

* For testing independence of distribution of tools causing injuries from the occupational group for the whole time period 2010-2014.

Table 6. Frequency of sharp injuries among nurses and midwives reported in the Łódź Province hospitals, Poland, 2010-2014, by used medical tools

\begin{tabular}{|c|c|c|c|c|c|c|}
\hline \multirow{2}{*}{ Variable } & \multicolumn{6}{|c|}{ Sharp injuries in consecutive years } \\
\hline & 2010 & 2011 & 2012 & 2013 & 2014 & total \\
\hline Needle injuries [n] & 109 & 90 & 99 & 102 & 83 & 483 \\
\hline within tool [\%] & 22.6 & 18.6 & 20.5 & 21.1 & 17.2 & 100.0 \\
\hline within year [\%] & 85.2 & 74.4 & 79.8 & 75.0 & 76.1 & 78.2 \\
\hline Stylet injuries [n] & 7 & 11 & 6 & 8 & 4 & 36 \\
\hline within tool [\%] & 19.4 & 30.6 & 16.7 & 22.2 & 11.1 & 100.0 \\
\hline within year [\%] & 5.5 & 9.1 & 4.8 & 5.9 & 3.7 & 5.8 \\
\hline Lancet/surgical knife injuries [n] & 7 & 11 & 9 & 11 & 7 & 45 \\
\hline within tool [\%] & 15.6 & 24.4 & 20.0 & 24.4 & 15.6 & 100.0 \\
\hline within year [\%] & 5.5 & 9.1 & 7.3 & 8.1 & 6.4 & 7.3 \\
\hline Cannula injuries [n] & 2 & 3 & 1 & 4 & 6 & 16 \\
\hline within tool [\%] & 12.5 & 18.8 & 6.3 & 25.0 & 37.5 & 100.0 \\
\hline within year [\%] & 1.6 & 2.5 & 0.8 & 2.9 & 5.5 & 2.6 \\
\hline Other injuries [n] & 3 & 6 & 9 & 11 & 9 & 38 \\
\hline within tool [\%] & 7.9 & 15.8 & 23.7 & 28.9 & 23.7 & 100.0 \\
\hline within year [\%] & 2.3 & 5.0 & 7.3 & 8.1 & 8.3 & 6.1 \\
\hline Total [n] & 128 & 121 & 124 & 136 & 109 & 618 \\
\hline within tool $[\%]$ & 20.7 & 19.6 & 20.1 & 22.0 & 17.6 & 100.0 \\
\hline within year [\%] & 100.0 & 100.0 & 100.0 & 100.0 & 100.0 & 100.0 \\
\hline Pearson's Chi ${ }^{2}$ test & \multicolumn{5}{|c|}{$\mathrm{Chi}^{2}=16.825$ for $\mathrm{p}=0.397$} & - \\
\hline
\end{tabular}


- measurement of blood glucose,

- intravenous cannulation,

- auxiliary activities when performing surgery.

The type of needle stick injuries that occurred most often were hypodermic needles, surgical suture needles, pen (insulin) needles, cannula needles, butterfly needles and blood collection needles. Scalpel, stylet, cannula and surgical knife are tools associated which a much lower rate of injury. The mean proportion of needle stick injuries to all other injuries reported by nurses during a year in time period 2010-2012 is equal to $78.2 \%$. The Pearson's Chi ${ }^{2}$ does not confirm changes in the years 2010-2014 in the distribution of type a sharp tool in a group of nurses.

\section{DISCUSSION}

Working with the patient is associated with the continuous risk of exposure to blood-borne infections. Occupational exposure to blood occurs with the majority of medical staff at least once a year, and the hands are the most exposed parts of the body [11]. The Birmingham study has demonstrated that $37 \%$ of medical personnel have experienced injury at least once, by used needles (53\% of doctors and $29 \%$ of nurses) [12]. In our study we have shown that it is the nurses that are more likely to be occupationally exposed to infectious material because this is a kind of profession which have the most frequent contact with the patient and potentially infectious material. Nurses perform many tasks of care and treatment, often using a needle. Ayranci and Kosgeroglu report that among 139 nurses surveyed, up to $52.5 \%$ had suffered injury more than once, by a used needle or other sharp medical instruments within 1 year. Nurses frequently experience injuries during injection $(34.5 \%)$ [13].

The Polish research also shows that among medical personnel, nurses are the group that is most frequently exposed to infectious material and the most frequent causes of injury are needles used earlier for injection [14-16]. For example, Różańska et al. in their study of 5 hospitals in the Małopolska province during 2008-2012 recorded a total of 775 cases of exposure to infectious material, most of which were experienced by nurses [17]. These reports are in line with our results, which show that the prevalence of needle stick injury was significantly higher ( $p \leq 0.05$ ) than the prevalence of injury by other medical instruments. Needle stick injuries were the most common causes of tissue disruption in all categories of medical staff.

Another question is the rate of occupational exposures reported in different registers. In our study, the annual average exposure rate has been 12.31 injuries per 1000 persons employed (95\% CI: 11.48-13.16/1000). In a retrospective study by Waclawski, the rate of injuries among medical personnel was 7.8 per 1000 employees per year (95\% CI: 6.8-9.4/1000) [18].

Since 2013 in Poland, the Minister of Health regulation on occupational health and safety when performing work associated with the risk of injury with sharp tools used when providing health care services has been in force, which imposes an obligation on the employer to keep a record of sharp injuries [3]. It would seem reasonable to expect that a law imposing a registration requirement is likely to increase the number of reported incidents of injuries caused by medical sharps. Our study, however, does not confirm that hypothesis. Likelihood of injury throughout 20102014 among medical staff was the same, and the number of reported injuries in 2014 (the year when the Regulation [3] had already been effective) was even lower than in the previous years (155 vs. 180 in 2013). The time between the Polish regulation [3] and surveillance data is probably too short to conclude that the law has no impact on registration but this may be the first signal to the fact that in addition to legislative changes other factors, that improve the effectiveness of the registration of adverse events, are still needed - this requires further study.

The research worldwide and the Polish studies confirm that a large number of occupational exposures are not recorded, and official reports may be underestimated (up to $50 \%$ of the events of exposure is not reported at all) [7-10,19]. 
Rybacki et al. found the most frequent reasons for not reporting accidental exposures, that were: lack of time to report, the feeling of a low risk of transmission for human immunodeficiency virus (HIV) and/or hepatitis B virus (HBV) or hepatitis $\mathrm{C}$ virus $(\mathrm{HCV})$ and the anxiety of being blamed or getting in trouble for having the exposure [7]. Further research should focus on identifying barriers to reliable reporting of the cases of exposure to potentially infectious material. At the same time, it seems advisable to take steps intended to raise awareness of medical personnel about the possible effects of exposure to infectious material, in particular, the benefits of implementation of early post-exposure procedures. We can speculate that no legislation will significantly improve the reliability of the data in the registers if the employees themselves do not feel the need to report incidents of exposure to potentially infectious material.

\section{Restrictions and limitations}

In collecting data, the authors encountered a number of limitations. Due to the different record-keeping practices (non-uniform registers in 2010-2013) in individual hospitals, it was not possible to attempt a more thorough analysis. The advantage is that an attempt was made to systematize data. The problem was also that some of the hospitals changed their administrative structure, and during those 5 years, various people had recorded the events in varied ways. Please keep also in mind that the collected data is merely approximate; it is not known how many people have failed to report the fact of puncture. A major advantage is that the data was collected from a large group of hospitals (51.5\%) from one Province (in Poland there is no authority obliged by law to collect such information).

\section{CONCLUSIONS}

It should be noted that:

- the incidence of injuries did not change significantly over the period 2010-2014, and the number of reported injuries in 2014 (the year when the Regulation [3] was made effective) was even lower than in the previous years. On average, each year there were 12 injuries per 1000 workers;

- the professional group most frequently exposed to infectious material is represented by nurses;

- the prevalence of needle stick injury was greater than the prevalence of injury by other medical instruments.

In our opinion, the procedure of keeping records of occupational exposures in all hospitals should be harmonized. And the most important, legal requirement to record occupational exposures alone will not improve the reliability of reporting actual incidents as long as employees do not feel the need to report exposures to infectious material (as shown by other studies).

\section{ACKNOWLEDGMENTS}

The authors thank the directors of the hospitals, who provided internal hospital data and made them accessible for publication, and Mr. Andrzej Olczyk for his help in data collection.

\section{REFERENCES}

1. Tarantola A, Abiteboul D, Rachline A. Infection risks following accidental exposure to blood or body fluids in health care workers: A review of pathogens transmitted in published cases. Am J Infect Control. 2006;34:367-75, https://doi. org/10.1016/j.ajic.2004.11.011.

2. Directive 2000/54/EC of the European Parliament and of the Council of 18 September 2000 on the protection of workers from risks related to exposure to biological agents at work. Off J Eur Communities L262/21 (Oct 17, 2000).

3. [Regulation of the Minister of Health of 6 June 2013 on occupational health and safety when performing work involving exposure to injury from sharp instruments used in providing health services]. J Laws 2013, No. 969. Polish.

4. Central Statistical Office. Research Department of Demographic and Labour Market. [Accidents at work in 2013. Information and statistical studies]. Warszawa: The Office; 2014. Polish. 
5. Centers for Disease Control and Prevention. Workbook for designing, implementing and evaluating a sharps injury prevention program [Internet]. Atlanta: The Centers; 2008 [cited 2016 Jan 16]. Available from: http://www.cdc.gov/ sharpssafety/pdf/sharpsworkbook_2008.pdf.

6. Prüss-Üstün A, Rapiti E, Hutin Y. Estimation of the global burden of disease attributable to contaminated sharps injuries among health-care workers. Am J Ind Med. 2005;48(6): 482-90, https://doi.org/10.1002/ajim.20230.

7. Rybacki M, Piekarska A, Wiszniewska M, Walusiak-Skorupa J. Work safety among Polish health care workers in respect of exposure to bloodborne pathogens. Med Pr. 2013; 64(1):1-10, https://doi.org/10.13075/mp.5893/2013/0001.

8. Gańczak M, Milona M, Szych Z. Nurses and occupational exposures to bloodborne viruses in Poland. Infect Control Hosp Epidemiol. 2006;27(2):175-80, https://doi.org/ 10.1086/500333.

9. Thomas WJC, Murray JRD. The incidence and reporting rates of needlestick injury amongst UK surgeons. Ann R Coll Surg Engl. 2009;91:12-7, https://doi.org/10.1308/00358 8409X359213.

10. Makary MA, Al-Attar A, Holzmueller CG, Sexton JB, Syin D, Gilson MM, et al. Needlestick injuries among surgeons in training. N Engl J Med. 2007;356:2693-9, https:// doi.org/10.1056/NEJMoa070378.

11. Narolska-Wierczewska E. Occupational exposures to blood and post-exposure preventive actions among the medical staff of hospitals on the example of the Kujawsko-Pomorskie Region [thesis]. Łódź: Nofer Institute of Occupational Medicine; 2005.

12. Stein A, Makarawo T, Ahmad M. A survey of doctors' and nurses' knowledge, attitudes and compliance with infection control guidelines in Birmingham teaching hospitals. J Hosp Infect. 2003;54:68-73, https://doi.org/10.1016/S01956701(03)00074-4.

13. Ayranci U, Kosgeroglu N. Needlestick and sharps injuries among nurses in the healthcare sector in a city of western Turkey. J Hosp Infect. 2004;58:216-23, https://doi.org/ 10.1016/j.jhin.2004.06.029.

14. Krawczyk P, Białkowska J, Dworniak D, Kamerys J, Szosland D, Jabłkowski M. Is healthcare personnel the only professional group exposed to the risk of occupational HBV, HCV or HIV infections? Med Pr. 2010;61(1):15-23.

15. Serafińska S, Smoliński P, Gładysz A. Critical evaluation of reporting on post exposure skin damage incidents and its consequences for Polish health workers. Med Pr. 2006; 57(5):439-50.

16. Garus-Pakowska A, Szatko F. Percutaneous exposures in medical personnel. Med Pr. 2011;62(5):473-80.

17. Różańska A, Szczypta A, Baran M, Synowiec E, Bulanda M, Wałaszek M. Healthcare workers' occupational exposure to bloodborne pathogens: A 5-year observation in selected hospitals of the Małopolska province. Int J Occup Med Environ Health. 2014;27(5):747-56, https://doi.org/10.2478/s13382014-0307-3.

18. Waclawski ER. Evaluation of potential reduction in blood and body fluid exposures by use of alternative instruments. Occup Med. 2004;54:567-9, https://doi.org/10.1093/occmed/ kqh116.

19. Gańczak M, Bohatyrewicz A, Korzeń M, Karakiewicz B. The comparison of sharps injuries reported by doctors versus nurses from surgical wards in the context of the prevalence of HBV, HCV and HIV infections. Pol J Surg. 2012;84(4): 190-5, https://doi.org/10.2478/v10035-012-0031-2.

This work is available in Open Access model and licensed under a Creative Commons Attribution-NonCommercial 3.0 Poland License - http://creativecommons.org/ licenses/by-nc/3.0/pl/deed.en. 